\title{
Investigating the Relationship between Quality of Work Life and Organizational Commitment amongst Employees in
}

\section{Malaysian Firms}

\author{
Normala, Daud \\ Faculty of Business Management, Universiti Teknologi MARA \\ 40450 Shah Alam, Selangor, Malaysia \\ Tel: 603-5544-4729 E-mail: dnormala@yahoo.com
}

\begin{abstract}
Determining the quality of work life (QWL) of employees is an important consideration for employers interested in improving employees' job satisfaction and commitment. The purpose of this paper was to investigate the relationship between quality of work life and organizational commitment among a sample of employees in Malaysia. Seven QWL variables were examined namely growth and development, participation, physical environment, supervision, pay and benefits and social relevance were examined to determine their relationship with organizational commitment. The results showed that there was a relationship between QWL and organizational commitment and provide insights on how Malaysian firms could improve upon their employees' commitment.
\end{abstract}

Keywords: Quality of work life, Organizational commitment, Malaysia

\section{Introduction}

The improvement of quality at the workplace is a concept that has captured the imagination of managers and workers alike. A number of researchers and theorists have been interested in the meaning of the quality of work life concept and have tried to identify the kinds of factors that determine such an experience at work (Kahn, 1981; Kalra \& Ghosh, 1984; Mirvis and Lawler, 1982; Kerce \& Booth-Kewley, 1993). Given the many perspectives by these researchers, the questions remain, what constitutes a high quality of work life? A high quality of work life (QWL) is essential for organizations to continue to attract and retain employees. According to Akdere (2006), the issue of work life quality has become critical in the last two decades due to increasing demands of today's business environment and family structure. May, Lau and Johnson (1999) suggested that companies offering better QWL and supportive work environments would likely gain leverage in hiring and retaining valuable people and companies with high QWL enjoy exceptional growth and profitability (Lau \& May, 1998). In the beginning, QWL is synonymous with employability rate, job security, earnings and benefits (Elizur \& Shye, 1990). This listing of objective criteria soon changed to job satisfaction as the target assessment criterion. Despite this shift to a more subjective construct, some researchers, such as Lawler (1975), remained convinced of the need for objective criteria to measure QWL.

To date studies on QWL and its relationships to organizational commitment in Malaysia countries have been somewhat limited (Mohd Hanefah, Md Zain, Mat Zain \& Ismail, 2003). Empirical research in this area especially amongst employees in Malaysian firms as well as Indonesia and Asian countries is still very scarce. It is the purpose of the present study to fill this vacuum that currently exists in the areas of QWL research.

\section{Purpose, Research Questions and Significance of the Study}

The purpose of this study was to determine a set of factors that can adequately represent the conception of a quality of work life. It aimed to investigate the perception Malaysian employees have on QWL and its relationship to organizational commitment in Malaysian firms. Specifically, the objectives of the study were to achieve the following: 1) to identify and determine the extent of quality of work life of employees in Malaysian scenario and 2) to investigate the relationship between the QWL and organizational commitment in Malaysian firms. This study was guided by two research questions:

1) What are the dimensions that represent the QWL; and

2) Are there any relationships between QWL and organizational commitment? 
The results of the survey were considered to be significant because they were intended to assist decision makers in identifying key workplace issues in order to develop strategies to address and improve the quality of working conditions in each organization.

\section{Past research on QWL}

There is a plethora of literature highlighting the factors critical for the assessment of QWL (Calson, 1978; Kalra \& Ghosh, 1974; Morton, 1977; Rosow, 1980; Srinivas, 1994; Walton, 1973). Attempts also have been made to empirically define QWL (Levine et al., 1984; Mirvis \& Lawler, 1984; Taylor, 1978; Walton, 1975). Comprehensive delineation of the QWL concept is found in three major works: Levine et al. (1984), Taylor (1978) and Walton (1975). Other researchers have attempted to measure QWL in a variety of settings using combinations of various questionnaires such as job satisfaction, organizational commitment, alienation, job stress, organizational identification, job involvement and finally work role ambiguity, conflict, and overload were studied as proxy measures of QWL.

There appeared to be no one commonly accepted definition for quality of work life. Heskett, Sasser and Schlesinger (1997) proposed that QWL, which was measured by the feelings that employees have towards their jobs, colleagues, and companies would enhance a chain effect leading to organization's growth and profitability. According to Havlovic (1991), Scobel (1975) and Straw and Heckscher (1984), the key concepts captured in QWL include job security, better reward systems, higher pay, opportunity for growth, and participative groups among others. Walton (1974) proposed the conceptual categories of QWL. He suggested eight aspects in which employees perceptions towards their work organizations could determine their QWL: adequate and fair compensation; safe and health environment; development of human capacities; growth and security; social integrative constitutionalism; the total life space and social relevance. In UK, Gilgeous (1998) assessed how manufacturing managers perceived their QWL in five different industries. Despite the growing complexity of working life, Walton's (1975) eight-part typology of the dimensions of QWL remains a useful analytical tool.

Using samples from Standard \& Poors 500 companies, Lau (2000) found that QWL companies have a higher growth rate as measured by the five-year trends of sales growth and asset growth. However, the outcome for profitability yield mixed results on Walton's (1974) conceptualisation of QWL. Saklani (2004) stressed that with the ever-changing technology and increased access to information, the study of organizations with respect to productivity, efficiency and quality of services very crucial in order to improve the performance of work in India. The need to improve organizational productivity in the health care industry has spurred Brooks and Anderson (2005) to develop the construct of quality of nursing work life. They came out with four dimensions of the conceptual framework namely; work life/home life dimension, work design dimension, work context dimension and work world dimension. In another study done by Wyatt and Chay (2001), they found four dimensions of quality of work life among the predominantly Chinese Singapore sample of employees. In Malaysia, Mohd. Hanefah et al. (2003), designed, developed and tested QWL measure for professionals, namely public and government accountants and architects. They conceptualized QWL as a multi-dimensional construct comprised of seven dimensions, namely growth and development, participation, physical environment, supervision, pay and benefits, social relevance and workplace integration. In summary, several studies that have examined QWL dimensions varied significantly not only across countries but also among researchers. This study was an attempt to further develop the dimensions of QWL in Malaysia.

\section{QWL and Organizational Commitment}

Organizational Commitment (OC) has been a popular topic of research in organizational behavior (Meyer \& Allen, 1997). OC refers to the strength of an employee's involvement in and identification with the organization (Hellrigel, Slocum \& Woodman, 1998). Allen and Meyer (1997) define OC as a psychological condition that relates the criteria in the employee relationship in the organization and the implications on the decision to remain in the organization. This means that committed employee will remain in the organization as compared to non-committed employee. According to Steers (1991), the sources of OC may vary from person to person. Caldwell (1990) suggests that OC is largely determined by the rewards offered by the organization, particularly financial rewards. Allen and Meyer (1990) conceptualized OC in terms of three distinct dimensions: affective, continuance and normative. Affective commitment is characterized by the presence of emotional attachment to the organization such that the affectively committed individual identifies with, is involved in and enjoys membership in the organization (Allen \& Meyer, 1990). The affectively committed employees remain with the organization because they want to (Meyer, Allen \& Gellatly, 1990). The continuance dimension of commitment refers to an awareness of the costs associated with leaving the organization. Employees whose primary link to the organization is based on continuance commitment remain because they need to do so (Meyer \& Allen, 1991). 
The normative dimension of $\mathrm{OC}$ focuses on feelings of loyalty to a particular organization resulting from the internalization of normative pressures exerted on an individual (Hackett, Bycio \& Hausdorf, 1994; Popper \& Lipshitz, 1992). O'Reilly and Chapman (1986) suggest that internalization occurs when the induced values of the individual and the organization are in congruence. Allen and Meyer (1990) also stress that individuals exhibit committed behaviors because it is the right thing to do. Employees who are normatively committed feel they ought to remain with the organization (Meyer \& Allen, 1991).

In Malaysia, studies on OC have been considered an important area in understanding employee behavior. Many researchers have examined and established the importance of OC in their studies (for example Aizzat, Ramayah \& Osman, 2001; Nik Mutasim, Mohd Adnan \& Amri, 2004; Rohani, Fauziah \& Illias, 2004). The accumulated research findings on OC to date have linked this construct to various antecedents and outcomes. However, with the exception of Mohd Hanefah et al. (2003), little is known about the relationship between QWL and OC in Malaysian and Asian countries' various firms. The present study defines QWL as favorable conditions and environments of work and life aspects such as growth and development, participation, physical environment, supervision, pay and benefits, social relevance and workplace integration. Better work experience may nurture employees' commitment to their organizations. Thus, it is assumed that there is a strong positive relationship between QWL and organizational commitment, meaning to say the higher the QWL the stronger will be the organizational commitment of employees.

\section{Methodology}

\subsection{Sample}

A predominantly quantitative approach was adapted for this study. Organizations were selected randomly. A total of sixty organizations were identified. Each organization was contacted to gain permission to distribute the questionnaires. Only fifty organizations agreed to be involved in the study. A random sample of 500 employees in the supervisory and executives levels in various firms in Malaysia received the questionnaire. Of these, 360 useable responses were returned and analyzed, which represented a $72 \%$ response rate.

\subsection{Variables Measure}

\subsubsection{Quality of work life}

Items included in the "Quality of Work Life Survey" were selected after a review of the literature. The instrument was pretested on a small group of employees. This pretesting was done to ensure the individuals could follow the instructions associated with the format and to identify items that were poorly written or ambiguous. A twenty eight (28) item questionnaire, derived and adapted from an earlier QWL study by Walton (1975) and modified by Mohd Hanefah et. al (2003) and Mat Zin (2004) were used to represent the seven dimensions of the quality of work life - growth and development, participation, physical environment, supervision, pay and benefits social relevance and workplace integration. Respondents were asked to indicate their agreement or disagreement about each QWL question with anchors ranging from strongly disagree (1) to strongly agree (7).

\subsubsection{Organizational commitment}

The measurement of commitment was based on the three components of organizational commitment developed by Allen and Meyer. This study used a twenty (20) item questionnaire to measure affective, normative and continuance commitment.

\subsection{Procedure}

The survey questionnaire was divided into 3 sections. The first section consisted of questions pertaining to QWL, the second section consisted of questions pertaining to OC and the last section was on the demographic and background information of the respondents. A cover letter outlining the purpose of the study was enclosed with the questionnaire.

\section{Results}

Of the respondents, 50.6 percent were male and 49.4 percent were female. The majority of the respondents was aged 30 and below (60.6\%), followed by $31-35$ years (18.9\%), 36-40 years (10\%), $41-45$ years $(6.1 \%)$ and above 45 years $(4.4 \%)$. Slightly more than half $(56.1 \%)$ of the respondents was single and 43.9 percent was married. More than three quarter of the respondents $(92.8 \%)$ were Malay while the rest $(7.2 \%)$ comprise of Chinese and Indians. The majority has bachelor's degree (43.9\%), certificate/diploma (43.3\%), secondary/higher secondary school (7.8\%) and professional and other qualifications (5.0\%). In terms of length of service, 87.2 percent of the respondents had less than 10 years of working experience of which 41.1 percent from this group had less than 2 
years of service. A majority of the respondents (33.9\%) worked in the administrative function, followed by human resource (18.3\%), IT (12.8\%) and banking and finance (10.6\%).

One of the important steps in data analysis is to understand the underlying dimensions or the proposed dimensionability of variables. A principal component factor analysis with varimax rotation was performed separately for items indicating QWL and OC variables. To determine whether there were seven QWL dimensions, the 28 items were subjected to principal component analysis. A common practice was to delete the non-performing items by adopting the criteria used by Igbaria, Iivari and Maragahh (1995). After deleting items that have cross loadings, a clean factor structure was produced. From the output, five factor solutions emerge with eigenvalues exceeding 1 .

The underlying dimensions of QWL and OC constructs were examined using principal component factor analysis with varimax rotation to determine their dimensions. Table 1 shows the result of the factor analyses. Results of factor analyses indicated that the QWL measure was found to be consisted of five dimensions. The factor loadings in the five factors range from .58 to .87 . Subsequently, the five factors were named accordingly.

Insert Table 1 here

The underlying dimensions of $\mathrm{OC}$ construct was examined using principal component factor analysis with varimax rotation to determine their dimensions. Table 2 shows the result of the factor analyses. Results of factor analyses indicated that the OC measure was found to be consisted of four dimensions. The factor loadings in the four factors range from .64 to .93 . Since the continuance commitment dimension is further divided into two sub-dimensions, similar to studies made by Mohd Hanefah et al. (2003) and Mat Zin (2004), the label of high cost and lack of employment alternatives were retained.

Insert Table 2 here

In order to describe the responses for the major variables under study, descriptive statistics such as mean and standard deviations on all the independent and dependent variables were obtained. Table 3 shows the overall results of mean, standard deviations and reliability coefficients of the QWL and OC dimensions.

From the results in Table 3, it can be seen that the mean of all QWL variables fall between 4.85 and 5.63. It appeared that respondents believed supervision, growth and development and social integration contributed highly to their quality of work life. As in the case of OC, the mean for OC variables fall between 4.59 and 5.66. In this case it appeared that the respondents have higher level of continuance commitment (costs), continuance (alternatives) and normative commitment compared to affective commitment.

Insert Table 3 here

Table 4 displays the results of regression analyses of QWL factors on the four dimensions of OC. Participation, social integration, growth and development, supervision, and pay and benefits were posited to have a positive relationship with affective commitment, normative commitment, continuance commitment (alternatives), and continuance commitment (costs).

\section{Affective Commitment}

From Table 4 it is observed that the QWL variables account for about 63 percent of the total variance in affective commitment. $\left(\mathrm{R}^{2}=0.626, \mathrm{~F}=118.45, \mathrm{p}<0.001\right)$. Four $\mathrm{QWL}$ factors are significant: growth and development $(\beta$ $=.09, \mathrm{p}<0.05)$, participation $((\beta=.042, \mathrm{p}<0.001)$, pay and benefits $(\beta=.32, \mathrm{p}<0.001)$ and social integration $(\beta$ $=.22, \mathrm{p}<0.001)$.

\section{Normative Commitment}

The results show that the QWL variables account for about 37 percent of the variance in the normative commitment $\left(\mathrm{R}^{2}=.37, \mathrm{~F}=40.81, \mathrm{p}<0.001\right)$. Three $\mathrm{QWL}$ variables have significant effects on normative commitment: growth and development $(\beta=.28, p<0.001)$, pay and benefits $(\beta=.20, p<0.001)$ and social integration $(\beta=.21, \mathrm{p}<0.001)$.

\section{Continuance Commitment (Alternatives)}

The results show that the QWL variables account for about 78 percent of the variance in the continuance commitment (alternatives) $\left(\mathrm{R}^{2}=.78, \mathrm{~F}=245.38, \mathrm{p}<0.001\right)$. All four $\mathrm{QWL}$ factors have significant effect on this dimension of commitment: growth and development $(B=.06, p<0.01)$, participation $((B=.09, \mathrm{p}<0.01)$, supervision $(\beta=.73, \mathrm{p}<0.001)$; pay and benefits $(\beta=.01, \mathrm{p}<0.001)$ and social integration $(\beta=.13, \mathrm{p}<0.001)$.

Continuance Commitment (Cost) 
The results show that the QWL variables account for about 23 percent of the variance in the continuance commitment $(\operatorname{cost})\left(\mathrm{R}^{2}=.23, \mathrm{~F}=20.86, \mathrm{p}<0.001\right)$. Three $\mathrm{QWL}$ variables have significant effects on this type of commitment: growth and development $(\beta=.13, \mathrm{p}<0.01)$, Participation $(\beta=.16, \mathrm{p}<0.01)$ and Supervision ( $(\beta$ $=.40, \mathrm{p}<0.001)$.

Insert Table 4 here

\section{Discussion and Conclusion}

Overall, the findings of the present study have provided answers to the research questions. The findings provided some insights in efforts to improve the quality of work life and organizational commitment among Malaysian employees. Growth and development has been indicated by respondents as a significant antecedent of all the four types of commitment under study; affective, normative, continuance (alternatives) and continuance (cost). Participation has significant positive relationship with affective, continuance (alternatives) and continuance (cost) commitments. As participation leads to involvement in the workplace, employees who perceive that they are given such opportunities would be more committed. Supervision has a significant positive relationship with continuance (alternatives) and continuance (cost) commitments. Pay and benefits has also been shown to have a significant positive relationship with affective, normative and continuance (alternatives) commitments. Fairness and the adequacy of their pay and benefits will spur the employees to be more committed to their organization. Likewise, social integration has also been shown to have a significant relationship with affective, normative and continuance (alternatives) commitments. Strong relationships and cohesiveness among employees in the workplace will improve their sense of commitments. The results of this research show that QWL and OC are a multidimensional construct and is a product of the evaluation of one's work place. This study provides valuable information about how employees in organizations view their work environment.

\section{Limitations of the Study and Directions of Future Research}

Several limitations exist in the present study that warrants review. First, the sample of this study was derived from non-managerial level of employees hence; this raises the issue of generalizability of findings. More research is needed before firm generalizable implications for non-managerial employees can be drawn. Second, the use of cross-sectional data limits inferences concerning causality between the predictor variables and the criterion variables. Since little research has been conducted using Malaysian samples in this area, the results of this study should be interpreted cautiously. The overall findings of this study are encouraging. However, the present results are by no means conclusive. The interpretation and specification of the quality of work life and organizational commitment that were empirically examined in the present study must be regarded as tentative.

Despite these limitations, the study's findings contributed to the extant literature by providing empirical evidence on the five components of QWL compared to eight components by Walton (1974). Another contribution of this study was that it empirically examined the relationships between QWL and the four-component model of organizational commitment.

\section{References}

Aizzat, M. N, Ramayah, T. \& Osman, M. (2001). Job satisfaction and organizational commitment among workers in Malaysian manufacturing companies. Proceedings of the $4^{\text {th }}$ Asian Academy of Management Conference. Asian Management in the new economy. Prospects and challenges. 10-13 November, Pahang Malaysia.

Akdere, M. (2006). Improving Quality of Work-Life: Implications for Human Resources. The Business Review, Cambridge, 6(1), December, 173- 177.

Allen, N.J., \& Meyer, J.P. (1990). The measurement and antecedents of affective, continuance and normative commitment to the organization. Journal of Occupational Psychology. 63(1). 1-18

Brooks, B. A., \& Anderson, M. A. (2005). Defining quality of nursing work life. Nursing Economics. Vol. 23 (6), Nov - Dec. 319 - 326.

Caldwell, D.F. (1990). Building organizational commitment: a multi-firm study. Journal of Occupational Psychology. 63, 245-261.

Calson, C. (1978). General Motors quality of work life efforts. Personnel, 55 (4): 11-23.

Davis, L.E. (1977). Enhancing the quality of working life: developments in the United States. International Labour Review. 116, 53-65. 
Elizur, D., \& Shye, S. (1990). Quality of work life and its relation to quality of life. Applied Psychology: An International Review. 39 (3), 275-291.

Gilgeous, V. (1998). Manufacturing managers: their quality of working life. Integrated Manufacturing Systems. 9/3, 173-181.

Havlovic, S. J. (1991). Quality of work life and human resource outcomes. Industrial Relations, Vol. 30, No. 3, Fall. $469-479$

Heckett, P.D., Bycio, P., \& Hausdorf, P.A. (1994). Further assessment of Meyer and Allen's three components model of organizational commitment. Journal of Applied Psychology. 79, 15-23.

Hellriegel, D., Slocum, J.W., \& Woodman, R.W. (1998). Organizational Behavior. $8^{\text {th }}$ edition, Oregon: South-Western College Publishing.

Igbaria, M., Iivari, J., \& Maragahh, H (1995). Why do individuals use computer technology? Information and Management. 5, p.227-238.

Kahn, R. (1981). Work and Health. New York; Wiley.

Kalra, S. K., \& Ghosh, S. (1984). Quality of work life: A study of associated factors. The Indian Journal of Social Work, 45-54.

Kerce, E., \& Booth-Kewley, S. (1993). Quality of work life surveys in organizations: methods and benefits. In P.

Lau, R. S. M., \& May, B. E. (1998). A win-win paradigm for quality of work life and business performance. Human Resource Development Quarterly. 9 (3), 211-226.

Lau, R. S. M. (2000). Quality of work life and performance - An ad hoc investigation of two key elements in the service profit chain model. International Journal of Service Industy Management. 11 (5), 422- 437.

Levine, M., Taylor, J., \& Davis, L. (1984). Defining quality of work life. Human Relations. 37, 81-104.

May, B. E., Lau, R. S. M., \& Johnson, S.K. (1999). A longitudinal study of quality of work life and business performance. South Dakota Business Review, 58 (2), 3-7.

Meyer, J.P., \& Allen, N.J. (1991). A three-component conceptualisation of organizational commitment. Human Resource Management Review. Vol. 1, no.1, 61-89.

Meyer, J.P., \& Allen, N.J. (1997). Commitment in the workplace: theory, research and application. California: Sage Publications.

Meyer, J.P., Allen, N.J., \& Gellatly, J. (1990). Affective and continuance commitment to the organization: evaluation of measures and analysis of concurrent and time-lagged relations. Journal of Applied Psychology. 75, 710-720.

Mirvis, P., \& Lawler, E. (1984). Accounting for the quality of work life. Journal of Occupational Behaviour. 5, 197-212.

Mohd. Hanefah, M., Md Zain, A.Y., Mat Zain, R., \& Ismail, H. (2003). Quality of work life and organizational commitment among professionals in Malaysia. Proceedings of the $1^{\text {st }}$ International Conference of the Asian Academy of Applied Business: Narrowing the competitive gap of emerging markets in the global economy. 10-12 July 2003 Sabah, Malaysia.

Morton, H. C. (1977). A look at factors affecting the quality of work life. Monthly Labour Review, October.

Nik Mutasim, A R, Mohd Adnan, A., \& Amri, A. (2003). Organizational commitment: a case of more than one dimension? a test within a sample of Malaysian bank officers. Proceedings of the $1^{\text {st }}$ International Conference of the Asian Academy of Applied Business: Narrowing the competitive gap of emerging markets in the global economy. 10-12 July 2003 Sabah, Malaysia.

O'Reilly, C.A., \& Chatman, J. (1986). Organizational commitment and psychological attachment: the effects of compliance, identification and internalisation on prosocial behavior. Journal of Applied Psychology. 71, 492-499.

Popper, M., \& Lipshitz, R. (1992). Ask not what your country can do for you: the normative basis of Organizational commitment. Journal of Vocational Behavior. 41, 1-12.

Rohani A. G., Fauziah, N., \& Ilias, M. (2004). Affective, continuance and normative commitment: an empirical study of academic staff in UiTM distance education program. Proceedings of the Conference on Scientific and Social Research, UiTM, Sarawak, Malaysia. 
Rosenfeld \& E. Jack (Eds.) Improving Organizational surveys: New directions, methods and applications. Sage focus editions, vol. 158. Newbury Park, CA, USA: Sage Publications.

Rosow, J. M. (1980). QWL issues in the 1980s. Training and Development Journal, 35: 33-52.

Saklani, D. R. (2004). Quality of Work Life in the Indian Context: An Empirical Investigation. Decision, Vol. 31 (2) July - December, 101-135.

Scobel, D. N. (1975). Doing away with the factory blues. Harvard Business Review. 53, Nov-Dec., $132-142$.

Srinivas, E. S. (1994). Perceived quality of work life (PQWL) and organizational commitment: A study of managers in selected organizations. In Nirmal Kr. Gupta and Abad Ahmad (ED.) Management Research: Contemporary Issues. New Delhi: South Asia Publications.

Straw, R. J., \& Heckscher, C.C. (1984). QWL: new working relationships in the communication industry. Labor Studies Journal. 8 Winter, 261-274.

Taylor, J. (1978). An empirical examination of the dimensions of quality of working life. Omega: International Journal of Management Science. 6, 153-160.

Walton, R. E. (1973). Quality of work life. Sloan Management Review, 15(1): 11-12.

Walton, R. E. (1974). QWL indicators: prospects and problems. In Portigal, A.H. (Eds.). Measuring the quality of working life. A symposium on Social Indicators of Working Life. Ottawa, March, 19-20.

Wyatt, T. A., \& Chay, Y. W. (2001). Perceptions of QWL; A study of Singaporean employees development. Research and Practice in Human Resource Management, 9(2), 59-76.

Table 1. Factor Analysis on the Dimensions of Quality of Work Life

\begin{tabular}{|c|c|c|c|c|c|}
\hline \multirow[t]{2}{*}{ Dimension } & \multicolumn{5}{|c|}{ Factor } \\
\hline & 1 & 2 & 3 & 4 & 5 \\
\hline Participation & $\begin{array}{l}.80 \\
.78 \\
.76 \\
.75 \\
.68 \\
.62\end{array}$ & & & & \\
\hline Social Integration & & $\begin{array}{l}.78 \\
.73 \\
.69 \\
.55\end{array}$ & & & \\
\hline Growth and Development & & & $\begin{array}{l}.82 \\
.76 \\
.70\end{array}$ & & \\
\hline Supervision & & & & $\begin{array}{l}.70 \\
.65\end{array}$ & \\
\hline Pay and benefits & & & & & $\begin{array}{l}.87 \\
.58 \\
\end{array}$ \\
\hline Eigenvalue & 7.03 & 2.12 & 1.68 & 1.28 & 1.15 \\
\hline Percentage variance explained & 35.17 & 10.62 & 8.39 & 6.38 & 5.77 \\
\hline Cronbach $\alpha$ & .88 & .82 & .77 & .73 & .67 \\
\hline
\end{tabular}


Table 2. Factor Analysis on the Dimensions of Organizational Commitment

\begin{tabular}{|lrrrr|}
\hline \multicolumn{1}{|c}{ Dimension } & \multicolumn{3}{c}{ Factor } & \\
& \multicolumn{1}{c}{2} & 3 & 4 \\
\hline Affective Commitment & .85 & & & \\
& .84 & & & \\
& .84 & & & \\
& .79 & & & \\
& .78 & & & \\
& .76 & & & \\
& .71 & & & \\
& .71 & & & \\
& .70 & & & \\
\hline Normative Commitment & .64 & & & \\
& & .82 & & \\
\hline Continuance Commitment (Alternatives) & & .81 & & \\
& & & .86 & \\
\hline Continuance Commitment (cost) & & & .84 & \\
& & & & .68 \\
\hline \\
Eigenvalue & & & & .78 \\
\hline Percentage variance explained & 6.92 & 2.18 & 1.42 & 1.20 \\
\hline Cronbach $\alpha$ & 40.69 & 12.81 & 8.37 & 7.05 \\
\hline
\end{tabular}

Table 3. Mean, Standard Deviation and Reliability Coefficients of QWL and organizational Commitment Scale

\begin{tabular}{|lrrr|}
\hline \multicolumn{1}{|c}{ Scale } & Mean & $\begin{array}{c}\text { Standard } \\
\text { Deviation }\end{array}$ & Reliability \\
\hline Participation & 4.85 & 1.07 & .88 \\
Social Integration & 5.20 & 1.00 & .82 \\
Growth and Development & 5.59 & .98 & .77 \\
Supervision & 5.63 & .90 & .73 \\
Pay and benefits & 4.88 & 1.10 & .67 \\
& & & \\
\hline Organizational Commitment & & & .93 \\
Affective & 4.59 & 1.27 & .71 \\
Normative & 5.00 & 1.25 & .74 \\
Continuance (alternatives) & 5.44 & 1.00 & .64 \\
Continuance (costs) & 5.66 & .92 & \\
\hline
\end{tabular}

Table 4. A Summary of Multiple Regression Analysis for QWL Factors Relating to Organizational Commitment

\begin{tabular}{|lcccc|}
\hline QWL Factor & $\begin{array}{c}\text { Affective } \\
(\beta)\end{array}$ & $\begin{array}{c}\text { Normative } \\
(\beta)\end{array}$ & $\begin{array}{c}\text { Continuance } \\
\text { (Alternatives) } \\
(\beta)\end{array}$ & $\begin{array}{c}\text { Continuance } \\
(\text { Cost }) \\
(ß)\end{array}$ \\
\hline Growth and Development & $.09^{*}$ & $.28^{* *}$ & $.06^{*}$ & $.13^{*}$ \\
Participation & $.42^{* *}$ & .07 & $.09^{*}$ & $.16^{*}$ \\
Supervision & .03 & .07 & $.73^{* *}$ & $.40^{* *}$ \\
Pay and benefits & $.32^{* *}$ & $.20^{* *}$ & $.10^{* *}$ & .02 \\
Social Integration & $.22^{* *}$ & $.21^{* *}$ & $.13^{* *}$ & .09 \\
& & & & .78 \\
\hline $\mathrm{R}^{2}$ & .63 & .37 & & .23 \\
$\mathrm{~F}$ & 118.45 & 40.81 & 245.38 & 20.86 \\
\hline
\end{tabular}

${ }^{*} \mathrm{p}<.01, * * \mathrm{p}<0.001$ 